\title{
Effect of Nano Surface Topography on Electrical Properties of Lead Sulfide (PbS) Films Deposited on Polymer Substrate
}

\author{
Mohammad Ghaffar Faraj
}

Department of Physics, Faculty of Science and Health, Koya University, University Park, Danielle Mitterrand Boulevard, Koya KOY45, Kurdistan Region-F.R. Iraq

\begin{abstract}
Lead sulfide (PbS) films were deposited on polymide (PI) plastic substrate chemical spray pyrolysis technique at substrate temperature in the range $250-350{ }^{\circ} \mathrm{C}$. Effects of substrate temperature on the electrical properties of the films were studied. In addition, the effect of nano surface topography on electrical properties of PbS films was studied. The deposited films were analyzed with atomic force microscope and Hall measurements to determine their electrical characteristics. AFM data shows that the root mean square (RMS) surface roughness of the PbS film increases with increasing substrate temperature. At room temperature, electrical resistivity of the PbS films varies from $9.54 \times 10^{3}$ to $1.14 \times 10^{3} \Omega . c m$, respectively.
\end{abstract}

Keywords: PbS, Polyimide, Chemical Spray Pyrolysis, Substrate Temperature, Electrical properties.

\section{INTRODUCTION}

$\mathrm{PbS}$ is a IV-VI compound semiconductor has a cubic lattice with unit cell face center cube [1-3]. These semiconductor materials have important properties as direct band gap and narrow gap with band gap energy of $0.4 \mathrm{eV}$. PbS thin films have been used in a lot of applications, including electronic and optoelectronic devices [4-6].

Thin films of $\mathrm{PbS}$ have been prepared with various physical and chemical thin film deposition techniques, such as chemical bath deposition [7], physical vapor deposition [8] and spray deposition [9].

Research on $\mathrm{PbS}$ on flexible polymeric substrates such as polyimide (PI) is gaining immense interests due to their flexibility, light-weight, low-cost (therefore potentially low-cost devices can be fabricated on top of $\mathrm{PI}$ ), high temperature resistance (typically up to $400{ }^{\circ} \mathrm{C}$ processing temperature), low coefficient of thermal expansion (CTE), low moisture uptake and high moisture release characteristics, excellent electrical properties and also increased voltage endurance [10]. Due to its superior properties, PI has found its applications as substrates in flexible thin film solar cells, flexible printed circuits and high density interconnects [11-13].

In this work, PbS thin films deposited on PI plastic substrate by chemical spray pyrolysis at different substrate temperatures $\left(250,300\right.$ and $\left.350{ }^{\circ} \mathrm{C}\right)$. The influence of substrate temperature on the electrical

*Address correspondence to this author at the Department of Physics, Faculty of Science and Health, Koya University, University Park, Danielle Mitterrand Boulevard, Koya KOY45, Kurdistan Region-F.R. Iraq; Tel: +96407701993794; E-mail: mohammad.ghaffar@koyauniversity.org properties of the PbS thin films was observed. The results obtained has been compared and discussed with the specified results by several researchers.

\section{EXPERIMENTAL PROCEDURE}

\subsection{Substrates Cleaning}

In this experiment, PI plastic was used as substrate. The PI plastic substrate was cleaned by alcohol for 10 min to remove contamination. After the cleaning process, all of the substrates were rinsed with distilled water (DI water). The samples were then dried with nitrogen $\left(\mathrm{N}_{2}\right)$ gas.

\subsection{Materials}

Lead (II) acetate trihydrate $\left(\mathrm{Pb}\left(\mathrm{CH}_{3} \mathrm{CO}_{2}\right)_{2} \cdot 3 \mathrm{H}_{2} \mathrm{O}\right.$; $99.99 \%)$, Thiourea $\left.\left(\mathrm{CS}\left(\mathrm{NH}_{2}\right)_{2}\right), \geq 99.0 \%\right)$

\subsection{Preparation of PbS Solutions}

In the preparation of $\mathrm{PbS}$ films, aqueous solutions of Lead (II) acetate trihydrate $\left(\mathrm{Pb}\left(\mathrm{CH}_{3} \mathrm{CO}_{2}\right)_{2} \cdot 3 \mathrm{H}_{2} \mathrm{O}\right.$ and Thiourea (CS $\left(\mathrm{NH}_{2}\right)_{2}$ ) with molarities of $0.1 \mathrm{M}$ and appropriate volumes were mixed with distilled water by using magnetic stirrer for 30 minutes and the resultant solution was sprayed on PI plastic substrates by chemical spray pyrolysis technique at different temperature (250-350) ${ }^{\circ} \mathrm{C}$. In order to get uniform thin films, the height of the spraying nozzle and the rate of spray process were kept constant during the deposition process at $35 \mathrm{~cm}$ and $15 \mathrm{~cm}^{3} / \mathrm{min}$, respectively. The spraying process lasted about 6 second. The period between spraying processes was about $1 \mathrm{~min}$; this period was enough to avoid excessive cooling of the substrate. The thickness of the prepared films was 
Roughness RMS $=6.1 \mathrm{~nm}$

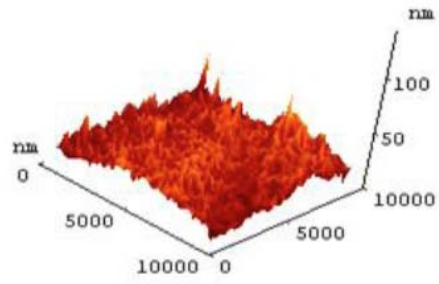

a
Roughness RMS $=13.16 \mathrm{~nm}$

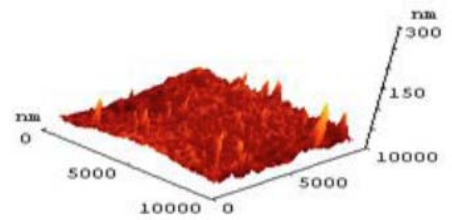

b
Roughness $\mathrm{RMS}=23.97 \mathrm{~nm}$

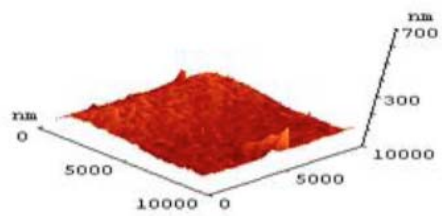

C

Figure 1: The AFM surface 3D images of $\mathrm{PbS}$ films as a function of substrate temperature:

(a) $250{ }^{\circ} \mathrm{C}$, (b) $300{ }^{\circ} \mathrm{C}$ and (c) $350{ }^{\circ} \mathrm{C}$.

about $600 \mathrm{~nm}$ measured by gravimetric method. The electrical properties of $\mathrm{PbS}$ thin films was measured by Hall measurements (HL5500PC) system. The surface morphology of the PbS films were studied by atomic force microscope (AFM) (Model: ULTRA1Objective model).

\section{RESULTS AND DISCUSSION}

AFM images for surface morphologies of $\mathrm{PbS}$ deposited on PI plastic substrates are given in Figure 1a-c. Figure 1 shows the variation of the film roughness with substrate temperature. The evaluated root mean square (RMS) surface roughness of the films, were $6.1 \mathrm{~nm}, 13.16 \mathrm{~nm}$ and $23.97 \mathrm{~nm}$ for films with a substrate temperature of $250{ }^{\circ} \mathrm{C}, 300{ }^{\circ} \mathrm{C}$ and $350{ }^{\circ} \mathrm{C} \mathrm{nm}$, respectively.

It should be noted that the RMS surface roughness increases with increasing substrate temperature. This behavior approximates previous reports [14-16].

The electrical measurements were carried out by Hall measurements. The electrical study reveals that the films have degenerate and exhibit n-type electrical conductivity. Figure 2 shows the electrical behavior of the $\mathrm{PbS}$ films as a function of substrate temperature. The film resistivity decreases dramatically as the substrate temperature is increased from 250 to $350{ }^{\circ} \mathrm{C}$. This behavior is in agreement with that reported in the literature $[17,18]$. The evaluated of film resistivity was $9.54 \times 10^{3}, 3.2 \times 10^{3}$ and $1.14 \times 10^{3}(\Omega . \mathrm{cm})$ at different temperature $\left(250,300\right.$ and $\left.350{ }^{\circ} \mathrm{C}\right)$.

\section{CONCLUSIONS}

Lead sulfide $(\mathrm{PbS})$ thin films were deposited on PI plastic substrates with chemical spray pyrolysis. Effects of substrate temperature on the electrical characteristics of the films deposited were experimentally investigated. The hall measurements show that the conductivity of the films is of $p$-type. The root mean square (RMS) roughness increased with increasing substrate temperature. It was observed that the increase of the substrate temperature decrease the resistivity film. This indicates with increasing the roughness, decrease the electrical resistivity of the films.

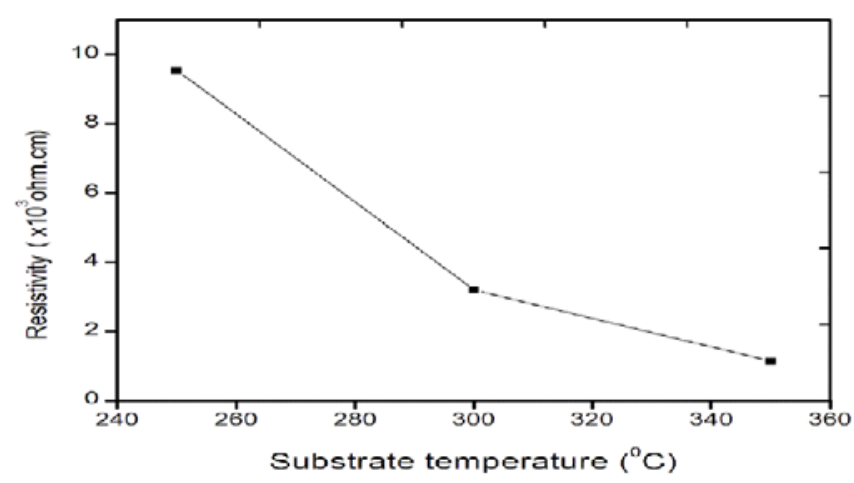

Figure 2: Resistivity of $\mathrm{PbS}$ films as a function of substrate temperature.

\section{ACKNOWLEDGEMENTS}

Hereby I would like to thank my home university "Koya University" and my sponsor the Ministry of Higher Education (MHE) of Kurdistan Regional Government (KRG) for enabling this study. The author thanks Mr. Mohd Zamir Pakhuruddin for help.

\section{REFERENCES}

[1] Lu X, Zhang M. Studies on PbS and PbSe detectors for IR system. International Journal of Infrared and Millimeter Waves 2000; 21: 1697-1701. http://dx.doi.org/10.1023/A:1006676029014

[2] Kumara D, Agarwal G, Tripathi B, Vyas D, Kulshrestha V. Characterization of $\mathrm{PbS}$ nanoparticles synthesized by 
chemical bath deposition. Journal of Alloys and Compounds 2009; 484: 463-6.

http://dx.doi.org/10.1016/.j.jallcom.2009.04.127

[3] Seghaier S, Kamoun N, Brini R, Amara BA. Structural and optical properties of $\mathrm{PbS}$ thin films deposited by chemical bath deposition. Materials Chemistry and Physics 2006; 97: 71-80.

http://dx.doi.org/10.1016/. matchemphys.2005.07.061

[4] Pop I, Nascu C, Ionescu V, Indrea E, Bratu I. Structural and optical properties of $\mathrm{PbS}$ thin films obtained by chemical deposition. Thin Solid Films 1997; 307: 240-4. http://dx.doi.org/10.1016/S0040-6090(97)00304-0

[5] Choudhury N, Sarma B. Structural characterization of lead sulfide thin films by means of $X$ - ray line profile analysis. Bulletin of Materials Science 2009; 32: 43-7. http://dx.doi.org/10.1007/s12034-009-0007-y

[6] Thiagarajan R, Beevi MM, Ramesh T. Influence of reactant concentration on nanocrystalline $\mathrm{PbS}$ thin films prepared by Chemical Spray Pyrolysis Optoelectronics and Advanced Materials - Rapid Communications 2012; 6: 132-5. http://oam-rc.inoe.ro/index.php?option=magazine \&op= view\&idu $=1784 \&$ catid $=70$

[7] Raniero L, Ferreira CL, Cruz LR, Pinto AL, Alves RMP. Photoconductivity activation in $\mathrm{PbS}$ thin films grown at room temperature by chemical bath deposition. Physica B: Condensed Matter 2010; 405: 1283-6. http://dx.doi.org/10.1016/j.physb.2009.11.068

[8] Sharon M, Ramaiah KS, Kumar M, Neumann-Spallart M, Levy- Clement C. Electrodeposition of lead sulphide in acidic medium. Journal of Electroanalytical Chemistry 1997; 436: 49-52. http://dx.doi.org/10.1016/S0022-0728(97)00124-1

[9] Thangaraju B, Kaliannan P. Spray pyrolytically deposited $\mathrm{PbS}$ thin films. Semiconductor Science and Technology 2000; 15: 849-53.

http://dx.doi.org/10.1088/0268-1242/15/8/311

[10] Kessler F, Rudmann D. Technological aspects of flexible CIGS solar cells and module. Solar Energy 2004; 77: 685-95. http://dx.doi.org/10.1016/j.solener.2004.04.010
[11] Pecora A, Maiolo L, Cuscunà M, Simeone D, Minotti A, Mariucci L, Fortunato G. Low-temperature polysilicon thin film transistors on polyimide substrates for electronics on plastic. Solid-State Electronics 2008; 52: 348-52.

http://dx.doi.org/10.1016/j.sse.2007.10.041

[12] Tiwari A N, Romeo A, Baetzner D, Zogg H. Flexible CdTe solar cells on polymer films.Progress in Photovoltaics: Research and Applications 2001; 9: 211-5. http://dx.doi.org/10.1002/pip.374

[13] Faraj MG, Pakhuruddin MZ. Deposited lead sulfide thin films on different substrates with chemical spray pyrolysis technique. International Journal of Thin Films Science and Technology 2015; 4: 215-7. http://www.naturalspublishing. com/Article.asp?ArtcID=9554

[14] Lee SU, Choi WS, Hong B. Synthesis and characterization of $\mathrm{SnO}_{2}: \mathrm{Sb}$ film by dc magnetron sputtering method for applications to transparent electrodes. Physica Scripta 2007; 2007: T129.

http://dx.doi.org/10.1088/0031-8949/2007/T129/069

[15] Li F, Jing C, Ling X, Wei-Ning S, Yao Y, Jun X, Zhong-Yuan M. Electron beam evaporation deposition of cadmium sulphide and cadmium telluride thin films: Solar cell applications. Chinese Physics B 2013; 22.

http://dx.doi.org/10.1088/1674-1056/22/9/098802

[16] Patel KJ, Desai MS, Panchal CJ. The influence of substrate temperature on the structure, morphology, and optical properties of $\mathrm{ZrO}_{2}$ thin films prepared by e-beam evaporation. Advanced Materials Letters 2012; 3: 410-4. http://vbripress.com/aml/uploads/1213531831

[17] Balasubramanian N, Subrahmanyam A. Effect of substrate temperature on the electrical and optical properties of reactively evaporated indium tin oxide films. Materials Science and Engineering: B 1988; 1: 279-81. http://dx.doi.org/10.1016/0921-5107(88)90008-6

[18] Wang S, Li X. Zhang J. Effects of substrate temperature on the properties of heavy Ga- doped $\mathrm{ZnO}$ transparent conductive film by RF magnetron sputtering. Journal of Physics: Conference Series 2009; 188: 012017. http://dx.doi.org/10.1088/1742-6596/188/1/012017 